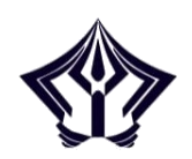

ANFUSINA: JOURNAL OF PSYCHOLOGY

http://ejournal.radenintan.ac.id/index.php/anfusina

DOI://dx.doi.org/10.24042/ajp.v2i1.4153

Volume 2, Nomor 1, April Tahun 2019

\title{
Pengaruh Penerapan Metode Vakt (Visual, Auditory, Kinesthetic, Tactile) Terhadap Peningkatan Kemampuan Membaca Permulaan Pada Siswa Kelas I Sekolah Dasar
}

\author{
Sandi Maspika, M. Psi., Psikolog \\ UIN Sulthan Thaha Saifuddin Jambi \\ sandimaspika@yahoo.com \\ Wahyu Kurniawan, M.Psi., Psikolog \\ Institut Agama Islam Negeri Syaikh Abdurrahman Siddik Bangka Belitung \\ wahyukurnia01@yahoo.com
}

\begin{abstract}
Reading is the basic capabilities that must be mastered in order to understand the knowledge. In reality, not all children have a good reading skills. To overcome this problem researcher choosed VAKT method. Researcher believed toward VAKT method effective to improve literacy ability on early elementary school students. This study aimed to determine how the influence of VAKT methods to improve reading ability at the beginning of first grade elementary school students. The subject on this study was the first grade elementary school students. The subject on this study consist of 5 students. Experimental design used in this study is quasi experiment. The data analysed by nonparametric (Wilcoxon). The results showed that VAKT method effective to improve reading skills at the beginning of the first grade students of elementary school. The result showed that $(z=-2.023, p=0,043$ ( $p<0.050)$. This study concluded that there was a significant difference between the ability to read at the beginning of the first grade students of elementary school before and after treatment. The reading ability at the beginning of the first grade students after the treatment is better than before the treatment.
\end{abstract}




\begin{abstract}
Abstrak
Membaca merupakan kemampuan dasar yang harus dikuasai anak agar dapat memahami berbagai pengetahuan. Dalam realitanya, tidak semua anak memiliki kemampuan membaca yang baik. Langkah terpenting untuk mengatasi permasalahan kemampuan membaca yang rendah adalah menerapkan metode dalam pembelajaran membaca khususnya dalam pembelajaran Bahasa Indonesia. Penerapan Metode VAKT merupakan salah satu cara untuk meningkatkan kemampuan membaca permulaan pada siswa kelas awal Sekolah Dasar. Penelitian ini bertujuan untuk mengetahui bagaimana pengaruh pelatihan metode VAKT terhadap peningkatan kemampuan membaca permulaan pada siswa kelas I Sekolah Dasar. Subjek penelitian ini yaitu siswa kelas I Sekolah Dasar. Penelitian ini menggunakan desain kuasi eksperimen. Subjek penelitian ini berjumlah 5 orang. Perlakuan yang diberikan kepada subjek adalah penerapan metode VAKT. Metode analisis data yang digunakan dengan teknik nonparametrik (Wilcoxon). Hasil penelitian menunjukkan bahwa penerapan metode VAKT berpengaruh terhadap peningkatan kemampuan membaca permulaan pada siswa kelas I Sekolah Dasar, dengan nilai $(\mathrm{z}=-2,023, \mathrm{p}=0,043(\mathrm{p}<0,050)$. Hal ini berarti bahwa kemampuan membaca permulaan pada pada siswa kelas I Sekolah Dasar setelah mendapatkan perlakuan mengalami peningkatan yang signifikan. Hal itu dapat diketahui dari kemampuan membaca permulaan setelah perlakuan lebih baik dari pada sebelum perlakuan.
\end{abstract}

Keyword: Implementation VAKT Method, Early Reading Ability

\title{
Pendahuluan
}

Sekolah dasar merupakan pendidikan formal yang menjadi dasar dalam mencari ilmu pengetahuan. Pendidikan di sekolah dasar sangat menentukan dalam pencapaian jenjang pendidikan selanjutnya. Pengajaran bahasa Indonesia di sekolah dasar memiliki arti dan peranan yang sangat penting bagi siswa, karena kepadanyalah mulamula diletakkan landasan keterampilan berbahasa Indonesia. Landasan berbahasa Indonesia akan tertanam pada anak didik apabila anak telah mampu memiliki keterampilan membaca. 
Menurut Abdurrahman (2012) Membaca merupakan kemampuan yang harus dimiliki oleh semua siswa, karena melalui membaca siswa dapat belajar banyak tentang berbagai bidang studi. Sementara itu, di dalam dunia pendidikan membaca mempunyai peranan yang sangat penting. Karena membaca merupakan suatu alat komunikasi yang sangat diperlukan untuk memperoleh informasi dan ilmu pengetahuan (Tarigan, 2011).

Thachir (1993) menyebutkan keterampilan membaca untuk siswa kelas satu adalah membaca permulaan. Pengajaran membaca permulaan di kelas satu sekolah dasar harus mendapat perhatian yang lebih besar. Membaca merupakan kunci masuknya ilmu pengetahuan. Keberhasilan membaca permulaan menjadi penentu berlangsungnya proses belajar mengajar berikutnya. Oleh karena itu guru dituntut untuk menerapkan metode yang tepat dalam pembelajaran keterampilan membaca permulaan. Penggunaan metode yang tepat sangat menentukan berhasil tidaknya proses belajar mengajar yang sedang berlangsung. Menurut Surakhman (Suryosubroto, 2002), menyebutkan metode adalah cara-cara pelaksanaan dari pada proses pengajaran, atau soal bagaimana teknisnya sesuatu bahan pelajaran diberikan kepada siswa-siswa di sekolah.

Namun faktanya, dalam pembelajaran membaca permulaan tidak semua anak dapat melewatinya dengan baik. Chall (dalam Kumara, 2012) menyatakan bahwa kegagalan anak dalam membaca akan berdampak pada kegagalan anak-anak dalam menguasai area akademik lainnya dan kegagalan tersebut akan semakin parah sesuai dengan naiknya jenjang sekolah anak yang bersangkutan.

Melihat kenyataan yang terjadi di SD N Patran Sleman. Berdasarkan studi pendahuluan yang peneliti lakukan pada tanggal 19 
September 2015, ada lima siswa yang duduk di kelas 1 memiliki kemampuan membaca yang cenderung rendah jika dibandingkan dengan siswa yang lainnya. Hal ini berdasarkan informasi yang peneliti terima dari wali kelas 1 yaitu ibu M, mengemukakan bahwa siswa kelas 1 secara keseluruhan berjumlah 31 orang dan lima siswa diantanya diindikasikan memiliki kemampuan membaca permulaan masih cenderung rendah. Rendahnya kemampuan membaca kelima siswa tersebut menurut guru dapat teridentifikasi dari kelancaran membaca, pelafalan dalam membaca, penggunaan intonasi, kenyaringan suara, dan pemahaman terhadap isi kalimat sederhana. Masalah yang mendasar pada saat siswa diminta untuk membaca adalah siswa masih kesulitan mengenali suku kata dan merangkainya menjadi kata, sehingga anak kesulitan membaca dengan lancar. Ketika diminta untuk membaca, siswa membaca dengan terbata-bata dan masih ragu-ragu untuk melafalkannya. Selain itu anak masih lamban dalam mengeja huruf menjadi kata. Sehingga ketika anak membaca satu kata saja anak akan membutuhkan waktu yang cukup lama dibandingkan temantemannya yang lain yang sudah bisa membaca. Padahal anak sudah mengenal huruf-huruf yang akan dirangkaikan.

Menyadari akan pentingnya kemampuan membaca semenjak kelas awal, maka diperlukan pembelajaran yang dapat meningkatkan kemampuan membaca siswa. Penggunaan metode yang tepat sangat menentukan berhasil tidaknya proses belajar mengajar yang sedang berlangsung. Menurut Surakhman (Suryosubroto, 2002), menyebutkan metode adalah cara-cara pelaksanaan dari pada proses pengajaran, atau soal bagaimana teknisnya sesuatu bahan pelajaran diberikan kepada siswa-siswa di sekolah. Menurut kurikulum berbasis kompetensi Bahasa Indonesia 2004, standar kompetensi mata pelajaran Bahasa 
Indonesia khususnya membaca permulaan, siswa diharapkan dapat membaca huruf, suku kata dan kalimat.

Berpijak dari permasalahan tersebut di atas, perlu dicarikan pemecahan masalah yaitu dengan diberikannya pendampingan yang dapat mengatasi hambatan membaca permulaan pada anak. Pendampingan tersebut adalah dengan diberikannya metode belajar membaca permulaan yang efektif sesuai dengan karakteristiknya. Menurut Abdurrahman (2012), salah satu metode yang diasumsikan dapat digunakan meningkatkan kemampuan membaca anak adalah metode visual auditori kinestetik taktil (VAKT).

Dipilihnya metode VAKT karena metode ini berdasarkan atas asumsi bahwa anak akan dapat belajar dengan baik jika materi pengajaran disajikan dalam berbagai modalitas. Modalitas yang sering dipakai adalah visual (penglihatan), auditory (pendengaran), kinesthetic (gerakan), dan tactile (perabaan). Keempat modalitas tersebut dikenal dengan VAKT. Pendekatan membaca multisensori meliputi kegitan menelusuri (perabaan), mendengarkan (auditori), menulis (gerakan) dan melihat (visual) (Yusuf, 2003). Di samping penggunaan metode VAKT dalam pembelajaran membaca, peran media diperlukan untuk dapat mendukung terlaksananya pembelajaran. Dalam metode VAKT penggunaan media berguna untuk menimbulkan gairah belajar, memungkinkan interaksi yang lebih langsung antara anak didik dengan lingkungan dan kenyataan serta memungkinkan anak didik belajar sendiri-sendiri menurut kemampuan dan minatnya (Sardiman, 2008). Selain itu, dipilihnya metode VAKT dengan alasan guru belum menggunakan metode ini dalam pembelajaran membaca sebelumnya karena guru biasanya 
menggunakan metode mengeja, melalui buku paket dan pemberian tugas yang dilakukan secara klasikal.

Metode VAKT menggunakan pendekatan multisensoris yang dapat digunakan dalam upaya penguasaan kosa kata pada siswa kelas awal yang masih dalam tahap membaca permulaan, karena pada proses membaca menuntut aspek penguasaan kosa kata yang meliputi pemahaman dan pemaknaan kata. Dipilihnya metode VAKT juga diharapkan agar anak mampu membaca dengan baik sesuai dengan usia perkembangannya. Dengan Metode VAKT, pembelajaran membaca siswa bisa lebih divariasikan melalui berbagai macam kegiatan yang dapat menunjang kemampuan membaca anak.

Berdasarkan uraian di atas, maka rumusan permasalahan yang akan dikaji dalam penelitian ini adalah: "Apakah penerapan Metode VAKT (Visual Auditory kinesthetic tactile) dapat meningkatkan kemampuan membaca permulaan pada siswa kelas I Sekolah Dasar?”.

\section{Metode Penelitian}

Sekolah dasar merupakan pendidikan formal yang menjadi dasar dalam mencari ilmu pengetahuan. Pendidikan di sekolah dasar sangat menentukan dalam pencapaian jenjang pendidikan selanjutnya. Pengajaran bahasa Indonesia di sekolah dasar memiliki arti dan peranan yang sangat penting bagi siswa, karena kepadanyalah mulamula diletakkan landasan keterampilan berbahasa Indonesia. Landasan berbahasa Indonesia akan tertanam pada anak didik apabila anak telah mampu memiliki keterampilan membaca.

Menurut Abdurrahman (2012) Membaca merupakan kemampuan yang harus dimiliki oleh semua siswa, karena melalui membaca siswa dapat belajar banyak tentang berbagai bidang studi. Sementara itu, di dalam dunia pendidikan membaca mempunyai peranan yang sangat penting. Karena membaca merupakan suatu alat komunikasi yang sangat diperlukan untuk memperoleh informasi dan ilmu pengetahuan (Tarigan, 2011). 
Thachir (1993) menyebutkan keterampilan membaca untuk siswa kelas satu adalah membaca permulaan. Pengajaran membaca permulaan di kelas satu sekolah dasar harus mendapat perhatian yang lebih besar. Membaca merupakan kunci masuknya ilmu pengetahuan. Keberhasilan membaca permulaan menjadi penentu berlangsungnya proses belajar mengajar berikutnya. Oleh karena itu guru dituntut untuk menerapkan metode yang tepat dalam pembelajaran keterampilan membaca permulaan. Penggunaan metode yang tepat sangat menentukan berhasil tidaknya proses belajar mengajar yang sedang berlangsung. Menurut Surakhman (Suryosubroto, 2002), menyebutkan metode adalah cara-cara pelaksanaan dari pada proses pengajaran, atau soal bagaimana teknisnya sesuatu bahan pelajaran diberikan kepada siswa-siswa di sekolah.

Namun faktanya, dalam pembelajaran membaca permulaan tidak semua anak dapat melewatinya dengan baik. Chall (dalam Kumara, 2012) menyatakan bahwa kegagalan anak dalam membaca akan berdampak pada kegagalan anak-anak dalam menguasai area akademik lainnya dan kegagalan tersebut akan semakin parah sesuai dengan naiknya jenjang sekolah anak yang bersangkutan.

Melihat kenyataan yang terjadi di SD N Patran Sleman. Berdasarkan studi pendahuluan yang peneliti lakukan pada tanggal 19 September 2015, ada lima siswa yang duduk di kelas 1 memiliki kemampuan membaca yang cenderung rendah jika dibandingkan dengan siswa yang lainnya. Hal ini berdasarkan informasi yang peneliti terima dari wali kelas 1 yaitu ibu M, mengemukakan bahwa siswa kelas 1 secara keseluruhan berjumlah 31 orang dan lima siswa diantanya diindikasikan memiliki kemampuan membaca permulaan masih cenderung rendah. Rendahnya kemampuan membaca kelima siswa tersebut menurut guru dapat teridentifikasi dari kelancaran membaca, pelafalan dalam membaca, penggunaan intonasi, kenyaringan suara, dan pemahaman terhadap isi kalimat sederhana. Masalah yang mendasar pada saat siswa diminta untuk membaca adalah siswa masih kesulitan mengenali suku kata dan merangkainya menjadi kata, sehingga anak kesulitan membaca dengan lancar. Ketika diminta untuk membaca, siswa membaca dengan terbata-bata dan masih ragu-ragu untuk melafalkannya. Selain itu anak masih lamban dalam mengeja 
huruf menjadi kata. Sehingga ketika anak membaca satu kata saja anak akan membutuhkan waktu yang cukup lama dibandingkan temantemannya yang lain yang sudah bisa membaca. Padahal anak sudah mengenal huruf-huruf yang akan dirangkaikan.

Menyadari akan pentingnya kemampuan membaca semenjak kelas awal, maka diperlukan pembelajaran yang dapat meningkatkan kemampuan membaca siswa. Penggunaan metode yang tepat sangat menentukan berhasil tidaknya proses belajar mengajar yang sedang berlangsung. Menurut Surakhman (Suryosubroto, 2002), menyebutkan metode adalah cara-cara pelaksanaan dari pada proses pengajaran, atau soal bagaimana teknisnya sesuatu bahan pelajaran diberikan kepada siswa-siswa di sekolah. Menurut kurikulum berbasis kompetensi Bahasa Indonesia 2004, standar kompetensi mata pelajaran Bahasa Indonesia khususnya membaca permulaan, siswa diharapkan dapat membaca huruf, suku kata dan kalimat.

Berpijak dari permasalahan tersebut di atas, perlu dicarikan pemecahan masalah yaitu dengan diberikannya pendampingan yang dapat mengatasi hambatan membaca permulaan pada anak. Pendampingan tersebut adalah dengan diberikannya metode belajar membaca permulaan yang efektif sesuai dengan karakteristiknya. Menurut Abdurrahman (2012), salah satu metode yang diasumsikan dapat digunakan meningkatkan kemampuan membaca anak adalah metode visual auditori kinestetik taktil (VAKT).

Dipilihnya metode VAKT karena metode ini berdasarkan atas asumsi bahwa anak akan dapat belajar dengan baik jika materi pengajaran disajikan dalam berbagai modalitas. Modalitas yang sering dipakai adalah visual (penglihatan), auditory (pendengaran), kinesthetic (gerakan), dan tactile (perabaan). Keempat modalitas tersebut dikenal dengan VAKT. Pendekatan membaca multisensori meliputi kegitan menelusuri (perabaan), mendengarkan (auditori), menulis (gerakan) dan melihat (visual) (Yusuf, 2003). Di samping penggunaan metode VAKT dalam pembelajaran membaca, peran media diperlukan untuk dapat mendukung terlaksananya pembelajaran. Dalam metode VAKT penggunaan media berguna untuk menimbulkan gairah belajar, memungkinkan interaksi yang lebih langsung antara anak didik dengan lingkungan dan kenyataan 
serta memungkinkan anak didik belajar sendiri-sendiri menurut kemampuan dan minatnya (Sardiman, 2008). Selain itu, dipilihnya metode VAKT dengan alasan guru belum menggunakan metode ini dalam pembelajaran membaca sebelumnya karena guru biasanya menggunakan metode mengeja, melalui buku paket dan pemberian tugas yang dilakukan secara klasikal.

Metode VAKT menggunakan pendekatan multisensoris yang dapat digunakan dalam upaya penguasaan kosa kata pada siswa kelas awal yang masih dalam tahap membaca permulaan, karena pada proses membaca menuntut aspek penguasaan kosa kata yang meliputi pemahaman dan pemaknaan kata. Dipilihnya metode VAKT juga diharapkan agar anak mampu membaca dengan baik sesuai dengan usia perkembangannya. Dengan Metode VAKT, pembelajaran membaca siswa bisa lebih divariasikan melalui berbagai macam kegiatan yang dapat menunjang kemampuan membaca anak.

Berdasarkan uraian di atas, maka rumusan permasalahan yang akan dikaji dalam penelitian ini adalah: "Apakah penerapan Metode VAKT (Visual Auditory kinesthetic tactile) dapat meningkatkan kemampuan membaca permulaan pada siswa kelas I Sekolah Dasar?”.

Variabel terikat dalam penelitian ini adalah Kemampuan membaca permulaan, sedangkan Variabel bebas adalah Motode VAKT. Kemampuan membaca permulaan adalah kapabilitas menterjemahkan isi tulisan atau simbol verbal yang tercetak menjadi kata-kata yang memiliki makna yang mencakup pengenalan huruf sebagai lambang bunyi-bunyi bahasa dan dilanjutkan dengan pemahaman isi bacaan. Adapun aspek yang yang digunakan untuk mengukur kemampuan membaca permulaan mengacu pada aspek yang dikemukakan oleh Tampubolon (2008), yaitu aspek kecepatan dan pemahaman.

Metode VAKT merupakan upaya pengoptimalan berbagai indera melalui berbagai aktivitas yang dapat menyebabkan anak yang memiliki hambatan belajar membaca permulaan dapat menangkap informasi atau pengetahuan dengan indera yang dimilikinya. Visual, auditori, kinestetik, dan taktil (VAKT) merupakan modalitas belajar anak yang harus diperhatikan. Orang visual belajar melalui apa yang 
dilihat, pelajar auditorial melakukannya melalui apa yang didengar, pelajar kinestetik belajar melalui gerak, dan pelajar taktil belajar melalui sentuhan (De Porter dan Hernacki, 2012).

Subjek penelitian adalah siswa kelas 1 SDN Patran, Sleman yang berjumlah lima orang dengan usia 7-8 tahun, siswa yang menjadi subjek dalam penelitian ini ialah siswa yang mengalami kesulitan dalam membaca permulaan. Pemilihan subjek tidak menggunakan sistem random, melainkan berdasarkan IQ (WISC) dan test kemampuan membaca yang disusun oleh Widyana, Safitri \& Purnamasari (2010) dengan karakteristik a) Duduk di kelas 1 sekolah dasar, b) Memiliki IQ dalam kategori rata-rata, c) Subjek mengalami kesulitan dalam membaca permulaan yang dapat dilihat dari tes kemampuan membaca awal yang disusun oleh Widyana, Safitri \& Purnamasari (2010) berdasarkan aspek kecepatan dan pemahaman. Adapun kemampuan membaca yang digunakan sebagai acuan dalam penelitian ini adalah batas bawah kemampuan membaca anak tingkat SD yang ditetapkan oleh Nuttal (dalam Somadayo, 2011), yaitu di bawah $60 \mathrm{kpm}$, artinya subjek memiliki kemampuan membaca yang cenderung rendah.

Sementara itu, desain eksperimen yang digunakan dalam penelitian ini adalah one group pretest-posttest design (Campbell \& Cronbach, 2002) merupakan desain eksperimen yang hanya menggunakan satu kelompok subjek (kasus tunggal) serta melakukan pengukuran sebelum perlakuan (pretest) dan sesudah perlakuan (posttest) pada subjek (Latipun, 2006).

Pemberian pretest dilakukan untuk mengetahui kemampuan membaca permulaan subyek sekaligus untuk penentuan kelompok eksperimen. Adapun pretest yang digunakan dalam penelitian ini ialah menggunakan Alat Tes Kemampuan Membaca Awal yang disusun oleh Widyana, Safitri, \& Purnamasari (2010). Dari hasil pretest subyek yang termasuk dalam kategori kemampuan membaca cenderung rendah kemudian dijadikan kelompok eksperimen. Setelah itu perlakuan (treatment) diberikan kepada subyek yang dieksperimen, 
berupa penerapan metode VAKT yang dimaksudkan untuk meningkatkan kemampuan membaca subjek. Kemudian 3 hari setelah treatment dilakukan pengukuran kemampuan membaca subjek sebagai data posttest. Adapun desain tersebut dapat dilihat sebagai berikut:

\section{Desain eksperimen (one group pretest posttest design)}

Pengukuran $\left(\mathrm{O}_{1}\right) \quad$ Manipulasi $(\mathrm{X}) \Rightarrow$ Pengukuran $\left(\mathrm{O}_{2}\right)$

Keterangan:

$\mathrm{O}_{1}$ : Kelompok eksperimen sebelum diberikan tes kemampuan membaca permulaan pretest

X: Deberi perlakuan (penerapan metode VAKT)

$\mathrm{O}_{2}$ : Kelompok eksperimen setetelah diberikan kemampuan membaca permulaan posttest.

Pada penelitian ini metode analisis data yang digunakan ialah dengan teknik analisis Wilcoxon sign rank test (Machfoedz, 2014). Digunakannya teknik analisis Wilcoxon karena pemilihan subjek tidak diambil secara random. Analisis data ini dilakukan untuk melihat perubahan kemampuan membaca permulaan subjek sebelum dan sesudah intervensi diberikan. Skor individu yang diperoleh digunakan sebagai dasar analisis. Apabila ada perbedaan antara skor pretest dan skor posttest, yaitu skor posttest lebih tinggi secara signifikan, maka dapat disimpulkan bahwa metode VAKT dapat meningkatkan kemampuan membaca permulaan. Proses analisisnya dilakukan dengan menggunakan program SPSS versi 16.

Kemudian untuk mendukung data kuantitatif, maka peneliti melakukan analisis kualitatif yang diperoleh dari hasil pengamatan yang dilakukan oleh observer selama proses pelaksanaan intervensi. Hal-hal yang diamati oleh observer, meliputi: proses pembelajaran (respon subjek terhadap instruksi fasilitator dan interaksi subjek terhadap subjek yang lain), dan proses perkembangan membaca subjek (daftar kata yang dibaca tepat dan daftar kata yang dibaca salah, serta bentuk kesalahan yang dilakukan). 


\section{Hasil dan Pembahasan}

Hasil penghitungan data empirik skor kemampuan membaca permulaan sebelum dan sesudah perlakuan. Adapun skor kemampuan membaca permulaan sebelum perlakuan yang doperoleh subjek penelitian, yaitu skor terendah $6.69 \mathrm{kpm}$ dan skor tertinggi sebesar $10.66 \mathrm{kpm}$ dengan rerata 8,61 kpm. Sedangkan skor kemampuan membaca permulaan setelah perlakuan yang diperoleh subjek, yaitu skor terendah $13.56 \mathrm{kpm}$ dan skor tertinggi sebesar $31.13 \mathrm{kpm}$ dengan rerata $20,15 \mathrm{kpm}$. Hal ini menunjukkan ada kenaikan rerata kemampuan membaca sebesar 11,54 kpm.

Meningkatnya kemampuan membaca permulaan semua subjek dikarenakan ada peningkatan dua aspek kemampuan membaca permulaan yang dikemukakan oleh Tampubolon (2008), yaitu kecepatan dan pemahaman. Berdasarkan data empirik skor aspek kecepatan membaca secara keseluruhan sebelum perlakuan yang diperoleh subjek penelitian, yaitu skor terendah $18.60 \mathrm{kpm}$ dan skor tertinggi sebesar $27.06 \mathrm{kpm}$ dengan rerata $22.29 \mathrm{kpm}$. Sedangkan skor aspek kecepatan membaca setelah perlakuan yang diperoleh subjek, yaitu skor terendah $23.62 \mathrm{kpm}$ dan skor tertinggi sebesar $41.17 \mathrm{kpm}$ dengan rerata $30,64 \mathrm{kpm}$. Hal ini menunjukkan ada kenaikan rerata kecepatan membaca sebesar 8,35 kpm.

Berdasarkan hasil dari perbandingan data empirik skor aspek pemahaman sebelum perlakuan dan setelah perlakuan di atas menunjukkan bahwa ada perbedaan antara subjek sebelum dan sesudah diberikan perlakuan melalalui penerapan metode VAKT. Kelima subjek mengalami peningkatan skor aspek pemahaman yang ditunjukkan dari perbandingan skor setelah perlakuan yang lebih tinggi dibandingkan skor sebelum perlakuan. Hal ini menunjukkan bahwa penerapan metode VAKT mampu meningkatkan aspek pemahaman pada kelima subjek penelitian.

Melalui peningkatan rerata aspek kecepatan membaca sebesar $8,35 \mathrm{kpm}$ dan aspek pemahaman sebesar $28 \%$, maka menjadikan rerata kemampuan membaca permulaan kelima subjek dalam penelitian ini juga mengalami peningkatan sebesar 11,54 kpm. 
Berdasarkan pada hasil analisis kuantitatif dengan menggunakan uji non parametrik wilcoxon signed ranks test menunjukkan nilai $\mathrm{Z}=-2,023$ dan $\mathrm{p}$ value $=0,043(\mathrm{p}<0,050)$, yang artinya ada perbedaan signifikan antara kemampuan membaca permulaan subjek sebelum dan sesudah diberikan perlakuan dengan menggunakan metode VAKT. Hal ini menunjukkan bahwa kemampuan membaca permulaan pada siswa kelas 1 Sekolah Dasar setelah mendapatkan perlakuan meningkat dibandingkan sebelum diberikan perlakuan. Peningkatan rerata kemampuan membaca permulaan tersebut terlihat dalam analisis deskriptif, yaitu sebesar $11,54 \mathrm{kpm}$.

Hasil ini juga didukung oleh data kualitatif yang menunjukkan bahwa secara umum subjek dalam pelatihan ini menyatakan adanya perubahan yang dirasakan setelah mengikuti pelatihan, diantaranya merasa lebih senang dan tidak cepat merasa bosan serta lebih konsentrasi pada saat membaca. Selain itu menurut peserta belajar dengan metode VAKT lebih menyenagkan karena belajar membaca dengan menggunakan media pembelajaran seperti media pasir, kartu kata, kartu kalimat dan huruf timbul yang terbuat dari styrofoam, sehingga membuat suasana belajar menjadi lebih menarik.

Pada awal proses pemberian perlakuan terhadap kelima subjek dengan menggunakan metode VAKT, tampak bahwa fasilitator dapat menjalin komunikasi yang hangat dengan cara menanyakan kabar subjek dan dilanjutkan dengan memperkenalkan diri kepada seluruh subjek, sehingga seluruh subjek yang menjadi peserta pelatihan mampu memberikan respon dengan menjawab pertanyaan fasilitator dan memperkenalkan diri secara bergantian. Adanya raport yang baik ini, sangat membantu fasilitator dalam pelaksanakan tahapan pemberian perlakuan selanjutnya.

Penerapan metode VAKT menggunakan pendekatan multisensori yang dapat merangsang empat modalitas alat indera, yaitu visual, auditoris, kinestetik, dan taktil. Melibatkan beberapa modalitas sekaligus, diharapkan anak dapat lebih mudah belajar dan menghasilkan kualitas belajar yang optimal. Sesuai prinsip VAKT, anak-anak di sekolah formal dapat memperoleh pengajaran membaca tidak hanya dari buku penunjang, namun langsung diarahkan pada 
penguasaan berbagai keterampilan visual, auditoris, kinestetik, dan taktil secara intensif dalam kelompok-kelompok kecil untuk mempermudah pengawasan guru dalam hal kemajuan belajar. Pengulangan yang dilakukan dapat memperkuat ingatan dan mempertajam analisis anak dalam menghubungkan informasi yang berkaitan dengan kata-kata yang sudah pernah dipelajari. Kesemuanya ini akan diharapkan akan mampu memaksimalkan fungsi-fungsi kognitif yang dapat mempercepat proses membaca pada siswa.

Dalam metode VAKT, perangsangan visual dan auditoris diberikan berurutan. Perangsangan visual melalui tulisan pada kartu kata, diikuti pengucapan oleh guru dan anak diminta mengikuti. Penyajian rangsang visual akan diperkuat dengan perangsangan auditoris sehingga anak lebih cepat dalam mengidentifikasi, membedakan, dan menyimpan kata-kata yang dipelajari. Selain ketrampilan visual dan auditoris, kepekaan taktil juga dapat mempercepat proses membaca. Perabaan memberi informasi tentang bentuk, ukuran, dan berat sebuah benda. Perabaan juga memperjelas tekstur permukaan dari suatu benda yang tidak jelas jika diamati secara visual (Blake \& Sekuler, 2006).

Proses terjadinya persepsi diawali ketika stimulus mengenai alat indera dan kemudian akan diteruskan oleh syaraf sensoris ke otak. Proses ini disebut sebagai proses fisiologis dalam persepsi. Selanjutnya, otak sebagai pusat kesadaran akan mengolah informasi sehingga individu menyadari apa yang dilihat, didengar, atau diraba. Proses di dalam pusat kesadaran inilah yang disebut proses psikologis. Fase terakhir dalam persepsi selanjutnya adalah individu menyadari apa yang diinderanya yang kemudian akan menghasilkan respon (Walgito, 2004).

Sementara itu, kemampuan mengkoordinasi gerakan tubuh (ketrampilan kinestetik) memiliki efek yang positif bagi anak yang sedang belajar membaca dan menulis (Ross, 1984). Koordinasi visualmotorik diperlukan saat anak menulis berurutan dari baris ke baris, memusatkan perhatian pada penguasaan kata yang terdiri dari simbol huruf atau kalimat, membentuk huruf yang tepat saat menulis, dan membedakan arah saat menulis. Perangsangan kinestetik dalam metode VAKT diberikan melalui praktik menulis di atas permukaan pasir. Bentuk huruf yang sudah dikenal anak melalui rabaan akan diwujudkan dalam bentuk tulisan. Menulis akan menambah hubungan 
antar neuron dan memperkuat jaringan syaraf, hal ini akan membentuk pola kompleks yang memungkinkan anak memiliki kemampuan untuk menerima informasi dari luar dan melakukan berbagai aktivitas (Tangada, 2003).

Belajar membaca melalui penerapan metode VAKT diwali ketika fasilitator memperlihatkan dan membacakan kartu kata yang terdiri dari huruf pada anak (visual, auditori), langkah kedua anak diminta untuk memilih dan mengambil kartu kata yang telah disediakan secara acak (visual, kinestetik, taktil), langkah ketiga anak menunjuk kartu kata dan menyusun kartu huruf timbul tersebut menjadi kata yang bermakna (visual, kinestetik, taktil), langkah keempat anak dibimbing menyebutkan susunan kartu kata dan melafalkan secara benar (auditori), langkah kelima anak dibimbing menelusuri huruf timbul dengan menggunakan jari telunjuknya serta mengucapkannya keras-keras (auditori, taktil), langkah keenam anak dibimbing blending atau menyatukan huruf menjadi kesatuan suku kata yang benar (visual, auditori), dan langkah terakhir ialah anak dibimbing untuk menuliskan kata yang telah dipelajari pada baki berisi pasir yang telah disediakan dan membaca apa yang telah ditulis (taktil, auditori).

Mengacu pada data deskripif, tampak bahwa metode VAKT mampu meningkatkan kecepatan membaca dan pemahaman subjek. Peningkatan rerata pemahaman subjek sebesar 28\% lebih tinggi dibandingkan peningkatan rerata kecepatan membaca sebesar 8,35 $\mathrm{kpm}$. Hal ini dikarenakan kelima subjek masih mengalami kesulitan dalam membaca kata dengan huruf KKV dan KKVK, sehingga ketika subjek menemui kata dengan huruf 'KKV dan KKVK', serta kata yang lebih panjang pada saat membaca materi Tes Kemampuan Membaca Awal setelah perlakuan, maka subjek akan cenderung mengejanya. Hal ini mengakibatkan, subjek cenderung mengurangi kecepatan dalam membaca kata tersebut, sehingga dapat mengurangi kecepatan membaca subjek.

Sementara itu, tingginya rerata peningkatan pemahaman dibandingkan kecepatan membaca karena meskipun subjek tidak membaca seluruh kata secara tepat, namun subjek masih dapat memahami isi dari suatu bacaan. Hal ini didasarkan pada pendapat Tampubolon (2008), bahwa ketika pembaca tidak membaca keseluruhan kata dalam suatu bacaan, maka pembaca masih bisa 
memahami maksud dari bacaan tersebut. Lebih lanjut Anderson (dalam Rahim, 2008), menambahkan bahwa pembaca memahami isi bacaan dengan menghubungkan konteks bacaan dengan pengetahuan yang sebelumnya pembaca miliki. Artinya meskipun dalam suatu teks bacaan tidak membahas secara eksplisit tentang suatu hal, maka pembaca dimungkinkan tetap dapat memahami teks tersebut berdasarkan pengalaman ataupun pengetahuan yang dimiliki.

Berdasarkan adanya peningkatan kecepatan membaca dan pemahaman, maka kemampuan membaca kelima subjek menjadi meningkat. Hal ini didasarkan pada pendapat dari Tampubolon (2008), bahwa kemampuan membaca mengacu kepada dua aspek, yaitu kecepatan membaca dan pemahaman, sehingga apabila kedua aspek tersebut meningkat, maka kemampuan membaca subjek juga akan mengalami peningkatan. Hal ini ditunjukkan dari hasil analisis deskriptif bahwa ada peningkatan rerata kemampuan membaca kelima subjek setelah diberikan perlakuan sebesar 11,54 kpm.

Berdasarkan uraian pembahasan di atas dapat ditarik kesimpulan, bahwa pemberian perlakuan dengan metode VAKT mampu meningkatkan kemampuan membaca permulaan kelima subjek penelitian. Dalam hasil penelitian ini menunjukkan pelatihan metode VAKT berpengaruh terhadap peningkatan kemampuan membaca permulaan siswa kelas awal. Hal itu terlihat dari peningkatan kecepatan membaca dan pemahaman siswa setelah mendapatkan perlakuan (posttest), dengan meningkatnya kedua aspek tersebut sehingga kemampuan membaca permulaan subjek juga mengalami peningkatan dengan signifikan. Maka dari hasil analisis yang telah dilakukan, dapat disimpulkan bahwa metode VAKT dapat meningkatkan kemampuan membaca permulaan pada siswa membaca kelas I Sekolah Dasar, sehingga hipotesis yang diajukan dalam penelitian ini diterima.

\section{Simpulan dan Saran}

Hasil penelitian menunjukkan bahwa penerapan metode VAKT berpengaruh terhadap peningkatan kemampuan membaca permulaan pada siswa kelas 1 Sekolah Dasar, dengan nilai $\mathrm{Z}=-2,023$ dengan taraf signifikansi sebesar $0,043(\mathrm{p}<0,050)$, yaitu dengan rerata peningkatan kemampuan membaca permulaan sebesar 11,54 kpm. Hal ini berarti bahwa kemampuan membaca permulaan pada pada siswa kelas 1 Sekolah Dasar setelah mendapatkan perlakuan mengalami 
peningkatan yang signifikan. Hal ini dapat diketahui dari kemampuan membaca permulaan setelah perlakuan lebih baik dari pada sebelum perlakuan.

Peningkatan kemampuan membaca permulaan pada subjek disebabkan dengan menggunakan metode VAKT pada saat intervensi, sehingga memberikan pengaruh positif pada diri subjek penelitian yaitu dengan berkurangnya kesalahan dalam membaca kata. Berkurangnya kesalahan dalam membaca kata tersebut pada saat Tes Kemampuan Membaca Permulaan setelah perlakuan, menunjukkan bahwa subjek mengalami peningkatan dalam proses visualisasi dan ingatan dengan memaksimalkan kemampuan visual, auditori, kinestetik dan taktil. Sementara itu subjek juga mengalami peningkatan pemahaman dalam membaca, dengan meningkatnya pemahaman subjek terhadap materi bacaan memberikan pengaruh pada kecepatan subjek dalam membaca kata.

\section{Referensi}

Abdurrahman, M. (2012) Pendidikan Bagi Anak Berkesulitan Belajar. Jakarta: Rineka Cipta.

Blake, R \& Sekuler, R. (2006). Perception (Edisi Revisi). New York: McGrew-Hill.

Campbell, D. T \& Cronbach, L. J. (2002). Experimental and QuasyExperimental Designs for Generalized Causal Inference. USA: Hongthon Maffin Company.

Kumara, A. (2012). Kesulitan Berbahasa Pada Anak, Deteksi Dini dan Penanganannya. Yogyakarta: Kanisius.

Latipun. (2006). Psikologi Eksperimen. Malang: UMM Press.

Machfoedz, I.(2014). Metode Penelitian Kualitatif \& Kuantitatif. Yogyakarta: Fitramaya.

Rahim, F. (2008). Pengajaran Membaca di Sekolah Dasar. Jakarta: Bumi Aksara.

Ross, E. P., Burns, P. C \& Roe, B. D. (1984). Teaching Reading In Today's Elementary School. Boston: Houghton Miffin Company. 
Sardiman, A. (2008). Metode Penelitian. Jakarta: PT RajaGrafindo Persada.

Sumadayo, S. (2011). Strategi dan Teknik Pembelajaran Membaca. Yogyakarta: Graha Ilmu.

Suryosubroto, B. (2002). Proses Belajar Mengajar di Sekolah. Jakarta: Rineka Cipta.

Tachir, A. M. (1993). Pandai Membaca dan Menulis I Petunjuk Guru Sekolah Dasar Kelas I. Jakarta: Depdikbud.

Tampubolon. (2008). Kemampuan Membaca Teknik Membaca Efektif Dan Efisien (Edisis Revisi). Bandung: Angkasa.

Tangada, J. (2003). Memahami Otak. Jakarta: Kompas.

Walgito, B. (2004). Pengantar Psikologi Umum. Yogyakarta : Andi Offset.

Widyana, R., Safitri R,M., \& Purnamasari, S.E. (2010). Validasi Alat Pengukuran (Assesment Tools) Kemampuan Membaca Awal. Jurnal Psikologi Pendidikan. Yogyakarta: Insigh. Vol, 8, (1), 14-36

Yusuf, M. (2003). Pendidikan Bagi Anak Dengan Problema Belajar. Solo: Tiga Serangkai Pustaka Mandiri. 